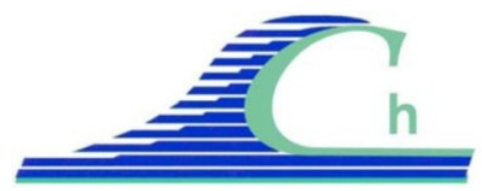

XII ${ }^{\text {̀̀mes }}$ Journées Nationales Génie Côtier - Génie Civil

Cherbourg, 12-14 juin 2012

DOI:10.5150/jngcgc.2012.049-S @ Editions Paralia CFL

disponible en ligne - http://www.paralia.fr - available online

\title{
Aménagement et évolution géomorphologique du littoral sableux de Sousse-sud (Golfe de Hammamet -Tunisie)
}

\author{
Mongi SOUAYED ${ }^{1}$
}

1. Université de Sousse - Institut Supérieur des Beaux-Arts de Sousse, Tunisie.

mongi_souayed@yahoo.fr

\section{Résumé :}

La zone du littoral sableux de Sousse-Sud, située dans la partie extrême sud du Golfe de Hammamet, s'étend du port de pêche et de commerce de la ville de Sousse au nord jusqu'au port de la centrale thermique au sud. Ce littoral a subi ces dernières décennies une évolution géomorphologique inquiétante suite à différents aménagements de protection qui y ont été réalisés. En effet depuis les années soixante après l'extension du port de pêche et de commerce de la ville, la partie sud du littoral a été assujettie à une érosion et un recul du trait de côte. La réalisation des aménagements de protection dans la partie nord de cette zone et l'installation de la centrale thermique à son extrémité sud dans les années quatre-vingt, ont accentué ce phénomène dont l'origine est la dynamique sédimentaire littorale engendrée par une de dérive littorale dominante vers le sud. Les stations de mesure fixées le long de cette frange montrent un recul du trait de cote qui a atteint dans certains endroits $2 \mathrm{~m} / \mathrm{an}$, alors que dans la partie extrême sud, à l'amont de la jetée du port de la centrale thermique on assiste à une avancée du trait de cote. La quantification de ce transit d'après la formule de Kamphuis (1991) jugée la plus fiable est estimée à $55000 \mathrm{~m}^{3}$ /an, puisqu'elle tient compte des grains des sédiments, de la pente de plage et surtout des caractéristiques de la houle au déferlement. La solution la plus appropriée proposée dans ce cas est mixte, il s'agit d'un rechargement en sable (plage artificielle), protégé par des ouvrages (brise-lames).

Mots-clés :

Littoral - Recul du trait de côte - Dérive littorale - Transit

\section{Communication non présentée}


Thème 2 - Dynamique sédimentaire 
XII ${ }^{\text {èmes }}$ Journées Nationales Génie Côtier - Génie Civil

Cherbourg, 12-14 juin 2012 
Thème 2 - Dynamique sédimentaire 
XII ${ }^{\text {èmes }}$ Journées Nationales Génie Côtier - Génie Civil

Cherbourg, 12-14 juin 2012 
Thème 2 - Dynamique sédimentaire 
XII ${ }^{\text {èmes }}$ Journées Nationales Génie Côtier - Génie Civil

Cherbourg, 12-14 juin 2012 
Thème 2 - Dynamique sédimentaire 
XII ${ }^{\text {èmes }}$ Journées Nationales Génie Côtier - Génie Civil

Cherbourg, 12-14 juin 2012 
Thème 2 - Dynamique sédimentaire 